\title{
Cerium Oxide-Polysulfone Composite Separator for an Advanced Alkaline Electrolyzer
}

\author{
Jung Won Lee ${ }^{1,2}{ }^{1}$, ChangSoo Lee ${ }^{1}$, Jae Hun Lee ${ }^{1}\left(\mathbb{D}\right.$, Sang-Kyung Kim ${ }^{1,3}{ }^{,}$, Hyun-Seok Cho ${ }^{1}$, \\ MinJoong Kim ${ }^{1}$, Won Chul Cho ${ }^{1, *}$, Jong Hoon Joo ${ }^{2,4, *}$ and Chang-Hee Kim ${ }^{1,3}$ \\ 1 Hydrogen Research Department, Korea Institute of Energy Research (KIER), 152 Gajeong-ro, Yuseong-gu, \\ Daejeon 34129, Korea; leejw792@kier.re.kr (J.W.L.); cs.lee@kier.re.kr (C.L.); jhlee@kier.re.kr (J.H.L.); \\ ksk@kier.re.kr (S.-K.K.); hscho@kier.re.kr (H.-S.C.); mj.kim@kier.re.kr (M.K.); chk14@kier.re.kr (C.-H.K.) \\ 2 Department of Urban, Energy, and Environmental Engineering, Chungbuk National University, \\ 1 Chungdae-ro, Seowon-gu, Cheongju, Chungbuk 28644, Korea \\ 3 Advanced Energy and System Engineering, Korea University of Science and Technology (UST), \\ 217 Gajeong-ro, Yuesong-gu, Daejeon 34113, Korea \\ 4 Department of Advanced Material Engineering, Chungbuk National University, 1 Chungdae-ro, Seowon-gu, \\ Cheongju, Chungbuk 28644, Korea \\ * Correspondence: wc.cho@kier.re.kr (W.C.C.); jhjoo@chungbuk.ac.kr (J.H.J.)
}

Received: 29 October 2020; Accepted: 24 November 2020; Published: 27 November 2020

\begin{abstract}
The intermittent and volatile nature of renewable energy sources threatens the stable operation of power grids, necessitating dynamically operated energy storage. Power-to-gas technology is a promising method for managing electricity variations on a large gigawatt (GW) scale. The electrolyzer is a key component that can convert excess electricity into hydrogen with high flexibility. Recently, organic/inorganic composite separators have been widely used as diaphragm membranes; however, they are prone to increase ohmic resistance and gas crossover, which inhibit electrolyzer efficiency. Here, we show that the ceria nanoparticle and polysulfone composite separator exhibits a low area resistance of $0.16 \Omega \mathrm{cm}^{2}$ and a hydrogen permeability of $1.2 \times 10^{-12} \mathrm{~mol} \mathrm{~cm}^{-1} \mathrm{~s}^{-1} \mathrm{bar}^{-1}$ in $30 \mathrm{wt} \%$ potassium hydroxide $(\mathrm{KOH})$ electrolyte, which outperformed the commercial separator, the Zirfon PERL separator. The cell using a $100 \mathrm{~nm}$ ceria nanoparticle/polysulfone separator and advanced catalysts has a remarkable capability of $1.84 \mathrm{~V}$ at $800 \mathrm{~mA} \mathrm{~cm}{ }^{-2}$ at $30 \mathrm{wt} \%$ and $80^{\circ} \mathrm{C}$. The decrease in the average pore size of $77 \mathrm{~nm}$ and high wettability (contact angle $75^{\circ}$ ) contributed to the reduced ohmic resistance and low gas crossover. These results demonstrate that the use of ceria nanoparticle-based separators can achieve high performance compared to commercial zirconia-based separators.
\end{abstract}

Keywords: alkaline water electrolyzer; ceria nanoparticle; diaphragm membrane; Zirfon separator; electrolytic cell

\section{Introduction}

The power-to-gas (PtG) process converts electric power into chemical energy to stably store energy for a long time [1-3]. The electrical energy is consumed for water splitting to produce hydrogen and oxygen using an electrolyzer. Polymer electrolyte membrane (PEM) electrolysis has a quick start, high flexibility, and better coupling properties with dynamic and intermittent systems [4,5]. Water electrolysis with alkaline electrolytes is recognized as a mature and reliable system. It is a technology based on cost and simplicity compared to other types of electrolysis [6-9]. Recently, alkaline electrolysis employing anion exchange membranes (AEMs) demonstrated a high rate of over $2 \mathrm{~A} \mathrm{~cm}^{-2}$ [10-12] and high flexibility that are comparable to PEM electrolysis [13,14]. However, AEMs still suffer from polymeric degradation and contamination from $\mathrm{CO}_{2}$ in the air after a 
performance test [15-17]. Thus, most commercial alkaline electrolyzers are operated while equipped with a diaphragm or porous separator as a membrane while circulating the electrolyte solution [18].

Composite porous separators are typically composed of hydrophilic inorganic materials combined with polymers. Polyantomonic acid was first developed for use in alkaline water electrolyzers because of its high alkali-resistance [19]. Potassium titanate [20], titania [21], sintered nickel plate [22], and zirconia [23-25] showed excellent stability in electrochemical systems as separator materials. Cerium oxide also shows excellent alkali-resistance and is utilized in many fields, such as magnetics, phosphors, alloys, and catalysis [26]. $\mathrm{CeO}_{2}$ was used to direct ethanol PEM fuel cells as a Pd support material because of the lowering of the onset energy of ethanol [27].

The pore structure of the separator, including pore size distribution, porosity, and average pore diameter, is a key performance parameter that influence the conductivity, permeability, and bubble point pressure of the porous separator $[28,29]$. The pore structure can be adjusted by controlling the nanoparticle, ratio of polymer in the suspension, mixing temperature, evaporation, etc. However, very little attention has been paid to the effect of nanoparticle size on the porous structure of the separator [30,31].

In this study, we synthesized a ceria-polysulfone (PSU) composite separator for use in an alkaline electrolyzer via a phase inversion process and performed in comparison with the commercial Zirfon PERL separator and the composite separators. The effect of the particle size of $\mathrm{CeO}_{2}$ on the key performance criteria was conducted regarding bubble point pressure, ionic resistance, and $\mathrm{H}_{2}$ permeability. The ceria-based separator was tested with respect to cell performance to evaluate the practicability in alkaline water electrolyzers.

\section{Experimental}

\subsection{Materials}

N-methyl-2-pyrrolidione (NMP, $\geq 99 \%$ ) and polyvinylpyrrolidone (PVP, K90 represents average molecular weights of 360,000) were supplied by Sigma-Aldrich (St. Louis, MO, USA), while polysulfone (PSU, Udel) was acquired from Solvay (Beveren, Belgium). $\mathrm{CeO}_{2}$ nanoparticles were purchased from US Nano Research (Houston, TX, USA) with various sizes of 10 to 30, 50, and $100 \mathrm{~nm}$. Polyphenylene sulfide mesh (PPS, PPS80PW, PVF Mesh and Screen Technology) was used as support. Distilled water (Pure Power I, Human science) and a $45 \mathrm{wt} \%$ potassium hydroxide $(\mathrm{KOH})$ solution (DAEJUNG) were used for preparing $30 \mathrm{wt} \% \mathrm{KOH}$ solution. The commercial Zirfon PERL separator was purchased from Agfa (Mortsel, Belgium).

The physical properties of the purchased $\mathrm{CeO}_{2}$ nanoparticles are summarized in Table 1 . The $\mathrm{C} 20$ separator was composite with $\mathrm{CeO}_{2}$ nanoparticles with sizes of $10 \mathrm{~nm}$ and $30 \mathrm{~nm}$; the Brunauer-EmmettTeller (BET) surface area and average pore diameter were $64 \mathrm{~m}^{2} \mathrm{~g}^{-1}$ and $9 \mathrm{~nm}$, respectively. The $\mathrm{CeO}_{2}$ nanoparticles of $50 \mathrm{~nm}$ and $100 \mathrm{~nm}$ had similar BET surface areas $\left(22-24 \mathrm{~m}^{2} \mathrm{~g}^{-1}\right)$ and average pore diameters (16 to $17 \mathrm{~nm}$ ).

Table 1. The physical properties for $\mathrm{CeO}_{2}$ nanoparticles.

\begin{tabular}{cccc}
\hline Sample & $\begin{array}{c}\text { BET Surface Area } \\
\left(\mathbf{m}^{\mathbf{2}} \mathbf{g}^{-\mathbf{1}} \mathbf{~}^{\mathbf{a}}\right.\end{array}$ & $\begin{array}{c}\text { Pore Volume } \\
\left(\mathbf{c m}^{\mathbf{3}} \mathbf{g}^{-\mathbf{1}} \mathbf{~}^{\mathbf{a}}\right.\end{array}$ & $\begin{array}{c}\text { Average Pore Diameter } \\
(\mathbf{n m})^{\mathbf{a}}\end{array}$ \\
\hline C20 & 64 & 0.154 & 9 \\
C50 & 23 & 0.094 & 16 \\
C100 & 24 & 0.104 & 17 \\
\hline \multicolumn{3}{c}{ a Brunauer-Emmett-Teller (BET) method (Tristar 3000, Micromeritics). }
\end{tabular}

\subsection{Separator Preparation}

The $\mathrm{CeO}_{2} / \mathrm{PSU}$ composite separators were synthesized by film casting method. PVP and PSU were blended with NMP using the mixing device (RED150-D, Pendraulik, Springe, Germany) and 
$\mathrm{CeO}_{2}$ nanopowder was added into the homogenous slurry. The composite ratio of $\mathrm{CeO}_{2}$ to $\mathrm{PSU}$ was fixed at $80 / 20 \mathrm{wt} \%$. Afterwards, the suspension was cast using a doctor blade apparatus. The PPS mesh was inserted in the center of the separator. After casting, the separator was dried in a convection oven (JEIO TECH. Co., Ltd., Daejeon, Republic of Korea) at a temperature of $90{ }^{\circ} \mathrm{C}$ for $20 \mathrm{~min}$. The solidified sample was deposited in distilled water to extract the solvent at $5^{\circ} \mathrm{C}$. The specimen (thickness $\sim 460 \mu \mathrm{m}$ ) was washed with deionized water several times and stored in deionized water. The synthesized separators were named the $\mathrm{CX}$ separator (where $\mathrm{X}$ is the average size of the $\mathrm{CeO}_{2}$ nanopowder). For example, the $\mathrm{C} 50$ separator indicates a separator that was prepared with $50 \mathrm{~nm} \mathrm{CeO}_{2}$ nanoparticles.

\subsection{Electrode Preparation}

Nickel foam material (NI003852) with porosity 110 pore per inch was obtained from Goodfellow Corp (Xiamen, China). In order to remove the oxides and impurities on the surfaces, Ni foams were soaked at $20 \mathrm{wt} \% \mathrm{NaOH}$ and $80{ }^{\circ} \mathrm{C}$ for $5 \mathrm{~min}$ and immersed in $18 \mathrm{wt} \% \mathrm{HCl}$ and $25^{\circ} \mathrm{C}$ for $5 \mathrm{~min}$. The Raney type nickel cathodes were prepared by a physical vapor deposition (PVD). The aluminum was sputtered on to porous nickel foams ( 1.6 mm thickness) by direct current magnetron sputtering (DC $300 \mathrm{~W}$ ), then heat-treated at $610^{\circ} \mathrm{C}$ for $150 \mathrm{~min}$. After the heat-treatment, the aluminum-coated nickel foam was immersed overnight in $30 \mathrm{wt} \%$ potassium hydroxide and a temperature of $80^{\circ} \mathrm{C}$ for selective aluminum leaching in gamma phase nickel-aluminum alloys. The NiFe layered double hydroxide (LDH) anode was fabricated by a $\mathrm{pH}$-controlled in-situ growth method. A clean iron foam was immersed into nickel sulphate solution and the $\mathrm{pH}$ level was controlled by continuous oxygen sparging into the solution for $7 \mathrm{~h}$ at a temperature of $50{ }^{\circ} \mathrm{C}$. The external voltage was not applied during the preparation process. After $7 \mathrm{~h}$, the sample was taken out and rinsed with deionized water and ethanol. The prepared LDH anode exhibited a Ni: Fe ratio of $1: 1$ containing $\mathrm{SO}_{3}{ }^{2-}$ as intercalated anions and the $\alpha-\mathrm{FeOOH} / \mathrm{NiFe} \mathrm{LDH}$ structure has been constructed successfully on the iron substrate.

\subsection{Characterization}

The scanning electron microscopy (SEM, S-4800, HITACHI, Tokyo, Japan) was used to investigate the microstructures of the prepared separators. To confirm construction of microscopic particles in the prepared separators, elemental mapping was conducted by Energy Dispersive X-ray Spectroscopy (EDS, Unti ${ }^{\circledR}$ Max, Oxford Instruments, Abingdon, UK). Prior to analysis, osmium was coated on the specimens to enhance the conductivities. The physical properties of fabricated separators, such as the porosity, average pore diameter, pore volume, and surface area, were studied by a gas adsorption (Tristar 3000, Micromeritics, Norcross, GA, USA) and a mercury porosimeter (Auto Pore 9520, Micromeritics, Norcross, GA, USA). The X-ray diffraction (XRD, Rigaku/D/max-2000 Ultima, Tokyo, Japan) analysis was conducted to determine the crystalline structure of composite separators and the Zirfon separator.

The bubble point pressure corresponding to the gas tightness was measured using the American Society for Testing Materials (ASTM) F316 procedure. The separator was located inside of the cell and was contacted with water and air on the upper side and the lower side, respectively.

To measure the conductivities of the $\mathrm{CeO}_{2} / \mathrm{PSU}$ composite separators, electrochemical impedance spectroscopy (SP240, BioLogic Science Instruments, Paris, France) with through-plane H-type cell (VB8-S, EC Frontier, Kyoto, Japan) was used. The specimen was placed between the cells with an active area of $3.14 \mathrm{~cm}^{2}$. The measurement was conducted at $30 \mathrm{wt} \% \mathrm{KOH}$ with an AC amplitude corresponding to $10 \%$ of the applied current density in the frequency range of $10 \mathrm{kHz}$ to $0.1 \mathrm{~Hz}$, and the conductivities of separators were obtained at $2 \mathrm{kHz}$.

To confirm the wettability of separators, the contact angle was measured by Washburn's approach. The separator samples were prepared a width $(\sim 20 \mathrm{~mm})$ and a length $(\sim 50 \mathrm{~mm})$ and dried in an oven for $12 \mathrm{~h}$ at a temperature of $90^{\circ} \mathrm{C}$. The resulting separator was deposited into a liquid ( $\left.30 \mathrm{wt} \% \mathrm{KOH}\right)$. Regarding time, the mass change was observed and the contact angle was recorded using the Washburn equation in detail elsewhere. [32]. 
A separator was prepared to an area of $24.45 \mathrm{~cm}^{2}$ and inserted into the center of the cell to measure the hydrogen permeability. The electrolyte ( $30 \mathrm{wt} \% \mathrm{KOH}$ solution) was used to thoroughly fill both sides of the cell at a temperature of $30^{\circ} \mathrm{C}$. The differential pressure was controlled from 1.1 to $1.5 \mathrm{bar}$ through a flowmeter (5850E, Brooks, Hatfield, PA, USA) and a back pressure controller (44-2361-24, Tescom Corp., Elk River, MN, USA). The higher-pressure side and lower side are referred to as the cathode and anode, respectively. The mass change permeated though the separator was obtained. The hydrogen permeability $\varepsilon_{\mathrm{H}_{2}}^{\text {Darcy }}\left(\mathrm{mol} \mathrm{cm}^{-1} \mathrm{~s}^{-1} \mathrm{bar}^{-1}\right)$ driven by the differential pressure can be defined as:

$$
\varepsilon_{H_{2}}^{\text {Darcy }}=\frac{K}{\eta} S_{H_{2}} P_{H_{2}}^{c a t}
$$

where $K$ denotes the electrolyte permeability $\left(\mathrm{cm}^{2}\right), S_{\mathrm{H}_{2}}$ is the solubility of hydrogen in the electrolyte $\left(\mathrm{mol} \mathrm{m}^{-3} \mathrm{bar}^{-1}\right), P_{\mathrm{H}_{2}}^{\mathrm{cat}}$ is the partial hydrogen pressure at the cathode side (bar), and the viscosity of the electrolyte is represented by $\eta$ (bar s). According to Darcy's law, the molar permeation flux density $\left(\Phi_{\mathrm{H}_{2}}^{\text {Darcy }}\right.$ in $\left.\mathrm{mol} \mathrm{cm} \mathrm{cm}^{-1} \mathrm{~s}^{-2}\right)$ of hydrogen via the separator driven by the differential pressure can be calculated as follows:

$$
\Phi_{H_{2}}^{\text {Darcy }}=-\varepsilon_{H_{2}}^{\text {Darcy }} \frac{\Delta p}{d}
$$

where $\Delta p$ denotes the differential pressure (bar) of both sides of the cell and $d$ indicates the thickness of the separator.

\subsection{Electrolysis Tests}

Rectangle-shaped electrodes and the separators were prepared based on $34.56 \mathrm{~cm}^{2}$ as an active area and assembled in a zero-gap type electrolytic cell with nickel-based porous transport layers (PTLs), bipolar plates (BPs), and a current collector. The cells were operated using $30 \mathrm{wt} \% \mathrm{KOH}$ electrolytes circulated with a flow rate of $450 \mathrm{sccm}$ at a temperature of $80{ }^{\circ} \mathrm{C}$. Cell voltage was recorded at a current density in a range from 0 to $2000 \mathrm{~mA} \mathrm{~cm}^{-2}$ by a potentiostat equipped with a booster (Advanced Power system N7970A, Agilent Technologies, Santa Clara, CA, USA). Galvanostatic electrochemical impedance spectroscopy (GEIS) was obtained at a current density of $200 \mathrm{~mA} \mathrm{~cm}^{-2}$ in a frequency range from $10 \mathrm{kHz}$ to $1 \mathrm{~Hz}$.

\section{Results and Discussion}

The cross-sectional SEM images of the $\mathrm{CeO}_{2}$-based separators and Zirfon separators are shown in Figure 1. From the low-magnification images (Figure 1a-d), the Zirfon separator has visible pores across the separators (Figure 1a). The C20 separator also had large pores (Figure 1b). On the contrary, no visible pores were observed for the $\mathrm{C} 50$ and $\mathrm{C} 100$ separators (Figure 1c,d). The polymeric layer and agglomerates were observed in the high-magnification images (Figure 1e,f). The Zirfon separator showed a layer of polymer several micrometers thick (Figure 1e). On the contrary, a distinct layer was not visible for the $\mathrm{CeO}_{2}$-based separators (Figure 1g,h). The composites of $\mathrm{ZrO}_{2}$ and PSU were randomly distributed for the Zirfon separator (Figure 1e) and the $\mathrm{CeO}_{2}$-based separators, including the $\mathrm{C} 50$ and C100 separators (Figure $1 \mathrm{~g}, \mathrm{~h}$ ). However, a few micrometers of agglomerations were clearly observed within the bulk of the $\mathrm{C} 20$ separator (Figure 1f). The $\mathrm{CeO}_{2}$ nanoparticles agglomerated to form large aggregates, as shown in (Figure $1 \mathrm{i}, \mathrm{j}$ ). $\mathrm{CeO}_{2}$ nanoparticles and polysulfone were well mixed with perfect compatibility for the $\mathrm{C} 50$ and $\mathrm{C} 100$ separators. SEM-EDS elemental mapping analysis showed that $\mathrm{CeO}_{2}$ nanoparticles were aggregated in the $\mathrm{C} 20$ separators. (Figure 11). Meanwhile, they were well dispersed in the C50 and C100 separators (Figure $1 \mathrm{~m}, \mathrm{n}$ ). 

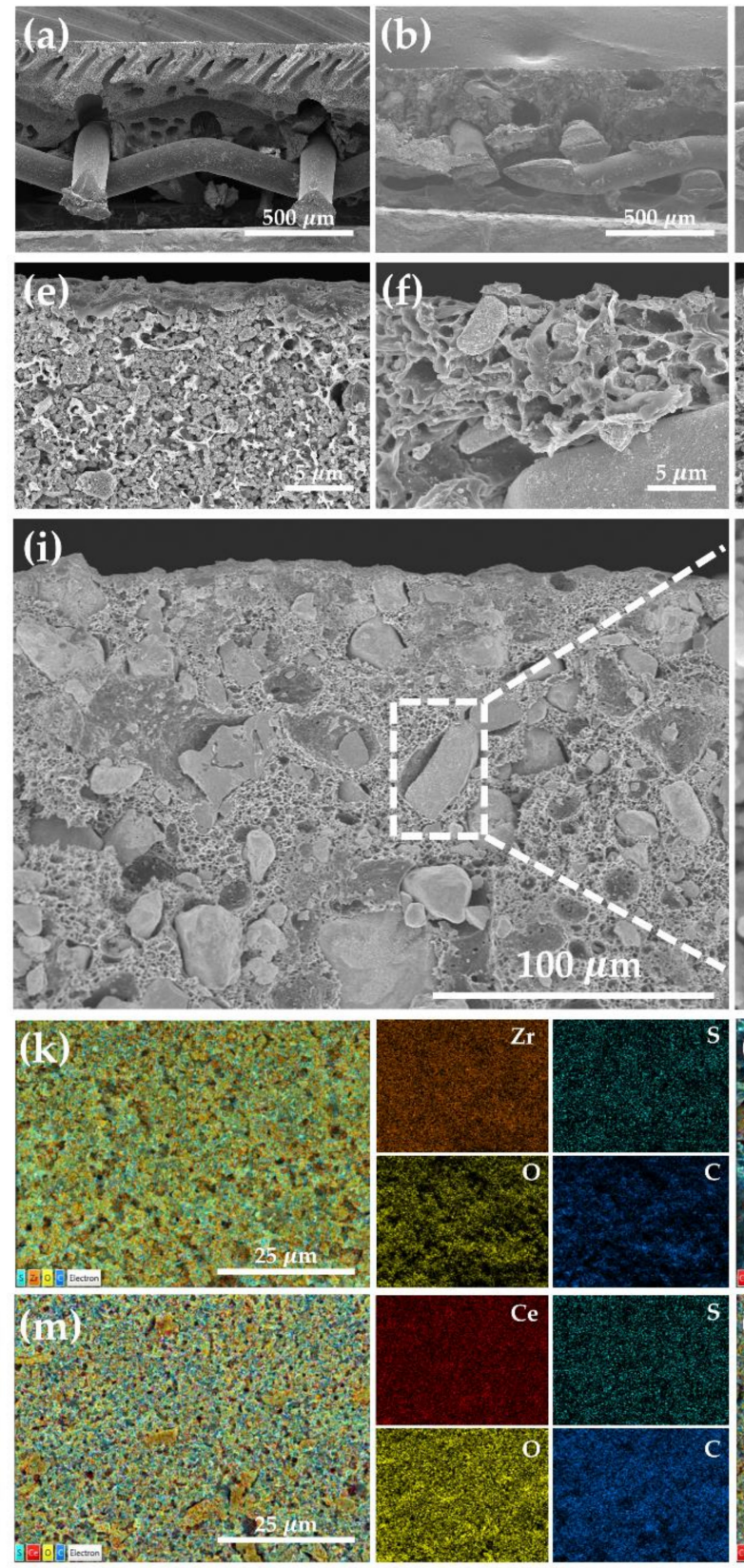
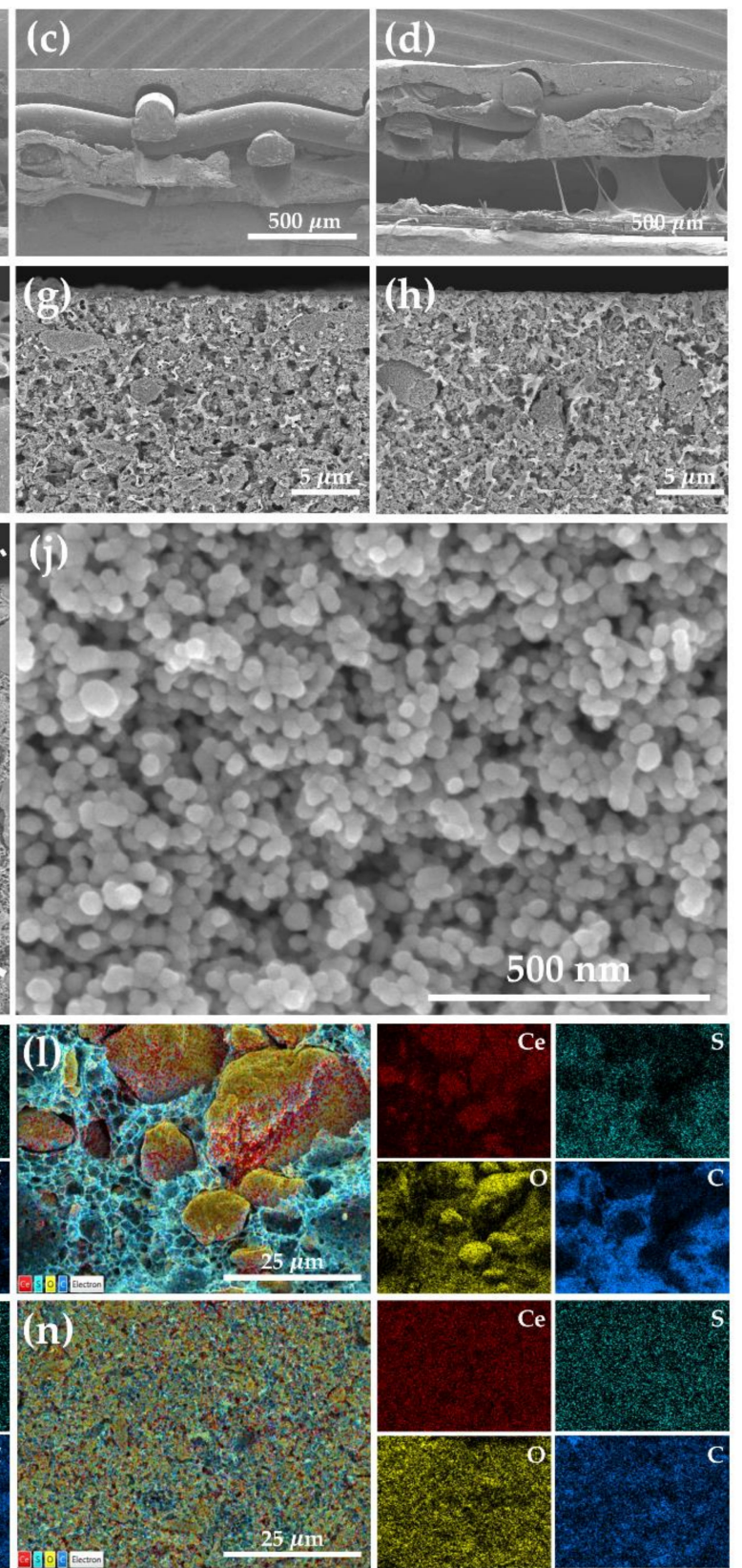

Figure 1. Cross-sectional SEM images, low-magnification (a) Zirfon, (b) C20 separator, (c) C50 separator, (d) C 100 separator and higher magnification (e) Zirfon, (f) C20 separator, (g) C50 separator, (h) C100 separator, and (i) aggregates of C20 separator (j) inset of agglomerated $\mathrm{CeO}_{2}$ nanoparticles. SEM-EDS elemental mapping analyses of (k) Zirfon, (1) C20 separator, (m) C50 separator, and (n) C100 separator.

The mercury-pore size distributions of the composite separators and the Zirfon separator are shown in Figure 2a. The separators showed a bimodal pore distribution. Smaller pores ranging from 10 to $50 \mathrm{~nm}$ are correlated to the pores between $\mathrm{CeO}_{2}$ nanoparticles, and the second larger pores are associated with the interconnected pores of the polymer matrix [25]. There was a narrow peak with a strong intensity in the micro-sized pores in the Zirfon separator. Meanwhile, the $\mathrm{CeO}_{2}$-based separators exhibited a decrease in the micro-size pores with reduced intensity. In addition, these separators showed a broad pore distribution from 10 to $300 \mathrm{~nm}$ with a relatively higher intensity than the Zirfon separator. The Hg porosimetry results of the separators are summarized in Table 2. The Zirfon separator had the largest average pore size of $116 \mathrm{~nm}$, which is related to a high portion of large pores. 
The $\mathrm{C} 20$ separator had the smallest average pore size of $51 \mathrm{~nm}$, which increased as the size of $\mathrm{CeO}_{2}$ nanoparticles increased. The $\mathrm{CeO}_{2}$-based separators exhibited a first broad pore distribution in the range of 10 to $50 \mathrm{~nm}$, which is associated with the shift in peaks shifted to the left toward smaller pore diameters.

(a)

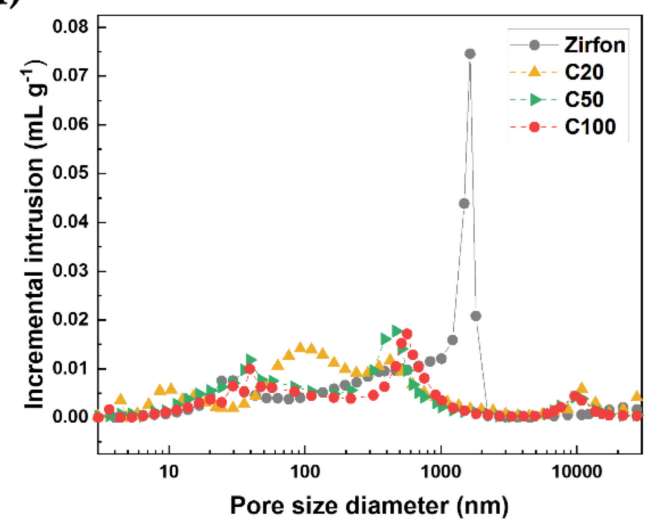

(b)

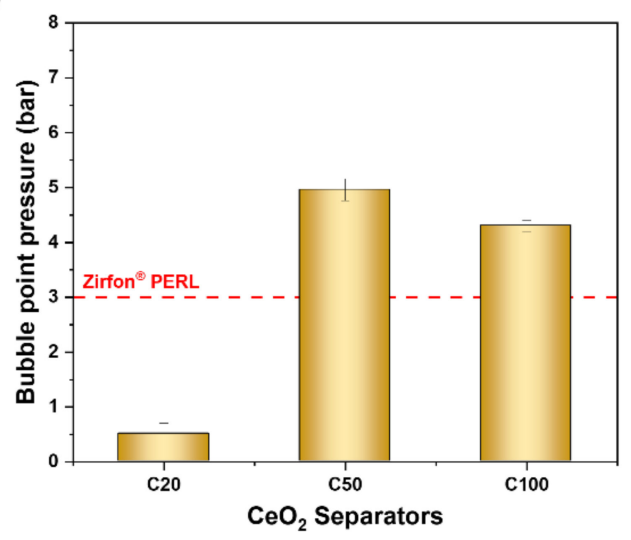

Figure 2. (a) Hg incremental intrusion volume curves and (b) bubble point pressure of the composite separators and Zirfon separator.

Table 2. Physical properties of composite separators and Zirfon.

\begin{tabular}{cccccc}
\hline & Unit & C20 & C50 & C100 & Zirfon \\
\hline Total pore area & {$\left[\mathrm{m}^{2} \mathrm{~g}^{-1}\right]$} & $40.1 \pm 0.5$ & $27.8 \pm 0.13$ & $18.6 \pm 0.3$ & $17.4 \pm 0.53$ \\
\hline Average pore diameter & {$[\mathrm{nm}]$} & $51 \pm 5$ & $62 \pm 3$ & $77 \pm 3$ & $116 \pm 10$ \\
\hline Bulk density & {$\left[\mathrm{g} \mathrm{mL}^{-1}\right]$} & $1.05 \pm 0.03$ & $1.21 \pm 0.025$ & $1.26 \pm 0.013$ & $1.08 \pm 0.29$ \\
\hline Apparent density & {$\left[\mathrm{g} \mathrm{mL}^{-1}\right]$} & $2.31 \pm 0.35$ & $2.56 \pm 0.27$ & $2.32 \pm 0.3$ & $2.37 \pm 0.5$ \\
\hline Porosity & {$[\%]$} & $54 \pm 3$ & $53 \pm 2$ & $46 \pm 2$ & $54 \pm 5$ \\
\hline Thickness & {$[\mu \mathrm{m}]$} & $455 \pm 20$ & $465 \pm 30$ & $460 \pm 25$ & $500 \pm 50$ \\
\hline Bubble point pressure & {$[\mathrm{bar}]$} & $0.5 \pm 0.2$ & $5 \pm 0.2$ & $4 \pm 0.1$ & $3 \pm 0.5$ \\
\hline
\end{tabular}

The bubble point pressure (BPP) for the composite separators is plotted in Figure 2b. Bubble point pressure is the minimum pressure required to force the liquid out of the pores, which is related to the pore size of the micropores of the membrane. According to Laplace's equation, the bubble point pressure depends on the maximum pore size $\left(R_{\max }\right)$ [31]. The C50 and C100 separators had larger BPP than the Zirfon separator, which exhibited the largest average pore diameter ( 116 nm). The BPP decreased from $5 \pm 0.2$ to $4 \pm 0.1$ bar as $\mathrm{CeO}_{2}$ nanoparticle size increased. A high BPP is inversely related to the small average pore size, which is in line with the average pore size in Table 2.

The area resistance and wettability as a function of synthesized $\mathrm{CeO}_{2}$ nanoparticle size are shown in Figure 3. The classical alkaline electrolyzer uses 25 to $30 \mathrm{wt} \% \mathrm{KOH}$ solution as an electrolyte because the polymeric membrane is still in research stages due to its instability under alkaline condition [33]. The porous separator should be filled with a concentrated electrolyte solution. The conductivity and wettability of the porous separator are responsible for the ohmic resistance. 
(a)

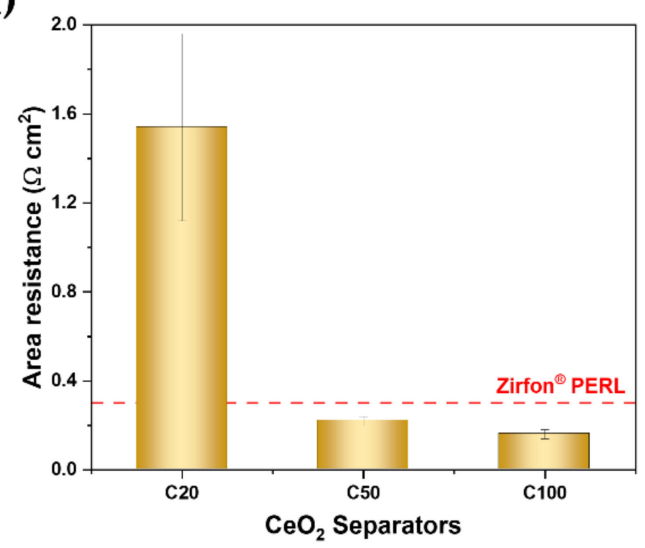

(b)

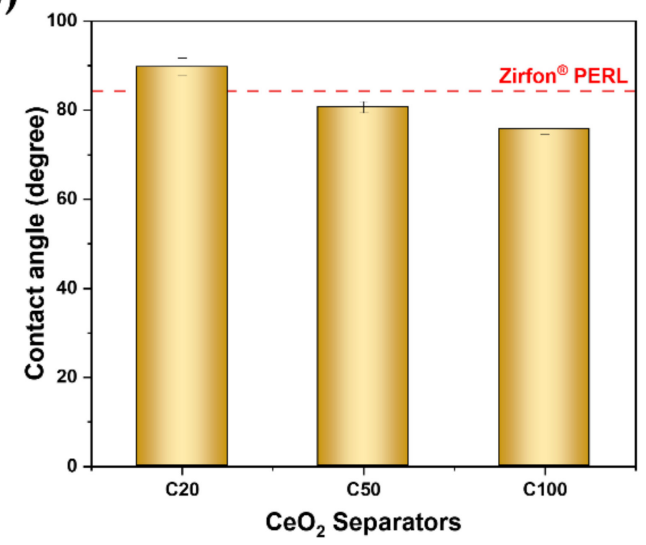

Figure 3. (a) Area resistance and (b) wettability of the composite separators and Zirfon.

The area resistance of the Zirfon separator, which was prepared with $40 \mathrm{~nm} \mathrm{ZrO}_{2}$ nanoparticles, was approximately $0.3 \Omega \mathrm{cm}^{2}$. The area resistance of the $C 20$ separator was $1.5 \pm 0.5 \Omega \mathrm{cm}^{2}$, and it decreased to $0.16 \pm 0.02 \Omega \mathrm{cm}^{2}$ as the $\mathrm{CeO}_{2}$ nanoparticle size increased (Figure 3a). The wettability decreased from 90 to $75^{\circ}$ as the synthesized $\mathrm{CeO}_{2}$ nanoparticle size increased (Figure $3 \mathrm{~b}$ ). The area resistance and wettability decreased as the porosity increased, as shown in Table 2 and Figure $3 b$, respectively. These results indicated that the preparation of the separator with larger $\mathrm{CeO}_{2}$ nanoparticles was recommended due to an increase in the average pore diameter of the prepared separator while maintaining high BPP.

The porous separator provides ionic conductivity by allowing aqueous electrolytes to pass through it while separating the evolving gases [28]. Aqueous electrolytes can permeate through the separator driven by the differential pressure. This permeability increased as porosity increased. The separator with high porosity showed low ohmic resistance but high permeability. Thus, there is a trade-off between ionic resistance and $\mathrm{H}_{2}$ permeability. The Zirfon separator has a micropore with a strong intensity (Figure 2), through which dissolved hydrogen in the electrolyte could permeate driven by the differential pressure [24], leading to a limited part-load range of the classic alkaline electrolyzer. Meanwhile, the polymeric electrolyte membrane in the PEM electrolyzer typically has nanopores of 2 to $5 \mathrm{~nm}$, which is responsible for low gas crossover by the differential pressure. A porous separator with smaller pores should be developed to reduce gas crossover driven by the differential pressure.

The $\mathrm{H}_{2}$ permeability of the Zirfon separator was as high as $20 \times 10^{-12} \mathrm{~mol} \mathrm{~cm}^{-1} \mathrm{~s}^{-1} \mathrm{bar}^{-1}$, as shown in Figure 4a. On the contrary, the $\mathrm{H}_{2}$ permeability of the $\mathrm{C} 20$ and $\mathrm{C} 50$ separators was $8.38 \pm 0.48 \times 10^{-12} \mathrm{~mol} \mathrm{~cm}^{-1} \mathrm{~s}^{-1} \mathrm{bar}^{-1}$ and $0.69 \pm 0.18 \times 10^{-12} \mathrm{~cm}^{-1} \mathrm{~s}^{-1} \mathrm{bar}^{-1}$, respectively. Figure $4 \mathrm{~b}$ shows the volumetric permeation flux density of the electrolyte via separators as a function of the absolute differential pressure. The cell temperature was $30^{\circ} \mathrm{C}$. The Zirfon separator showed the highest volumetric permeation flux density, followed by the C20, C100, and C50 separators. These results are consistent with the average pore sizes of the separators in Table 2. Notably, the C100 separator exhibited a low ohmic resistance $\left(0.16 \Omega \mathrm{cm}^{2}\right)$ and low hydrogen permeation flux density $\left(1.2 \times 10^{-12} \mathrm{~mol} \mathrm{~cm}^{-1} \mathrm{~s}^{-1} \mathrm{bar}^{-1}\right)$, which comprise only about $50 \%$ of the Zirfon separator's resistance and $6 \%$ of the Zirfon separator's $\mathrm{H}_{2}$ permeability, respectively. 
(a)

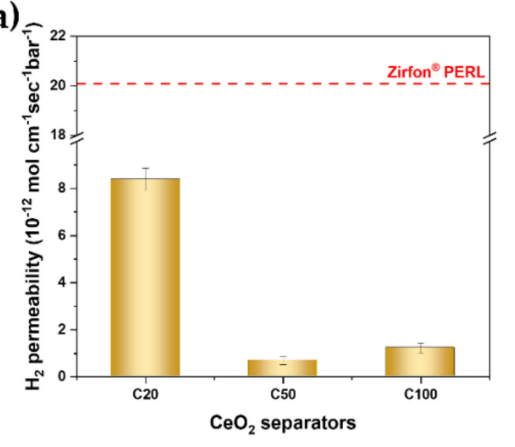

(b)

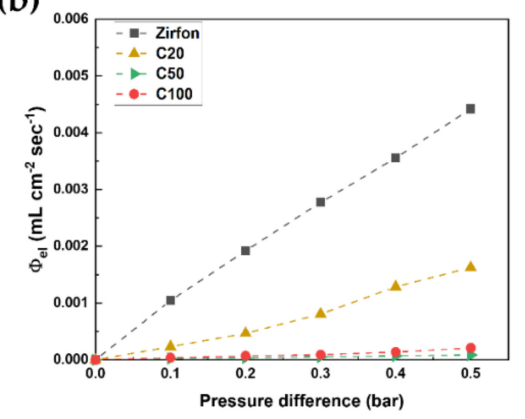

Figure 4. (a) $\mathrm{H}_{2}$ permeability (b) volumetric permeation flux density of the composite separators and Zirfon.

The polarization characteristics of the cell in various combinations with catalysts and separators are shown in Figure 5. The cells were equipped with a nickel-foam electrode at a temperature of $80^{\circ} \mathrm{C}$ and $30 \mathrm{wt} \% \mathrm{KOH}$ solution and are presented in Figure $5 \mathrm{a}$. The differences between the separators increased with the higher current density owing to the ohmic resistance. The C20 separator showed poor performance, while the $\mathrm{C} 100$ separator showed the best performance. The cell equipped with the C100 separator achieved $59 \%$ voltage efficiency at $2000 \mathrm{~mA} \mathrm{~cm}^{-2}$. The current-voltage polarization curves for Raney-Ni as the hydrogen evolution reaction (HER) electrode and LDH as the oxygen evolution reaction (OER) electrode are shown in Figure 5b. The cell employing the C100 separator showed a higher performance of $2.2 \mathrm{~V}$ at $2000 \mathrm{~mA} \mathrm{~cm}^{-2}$ than that of the Zirfon separator $(2.5 \mathrm{~V}$ at $2000 \mathrm{~mA} \mathrm{~cm}{ }^{-2}$ ), enhancing the voltage efficiency by $67 \%$. The ohmic resistances of the separators measured by the Nyquist plot (Figure $5 c, d$ ) were in line with the ex situ results (Figure 3). The results suggest that the $\mathrm{CeO}_{2}$-based separator could contribute to improving the voltage efficiency due to high wettability while lowering the $\mathrm{H}_{2}$ permeability resulting from the reduced average pore size.

(a)

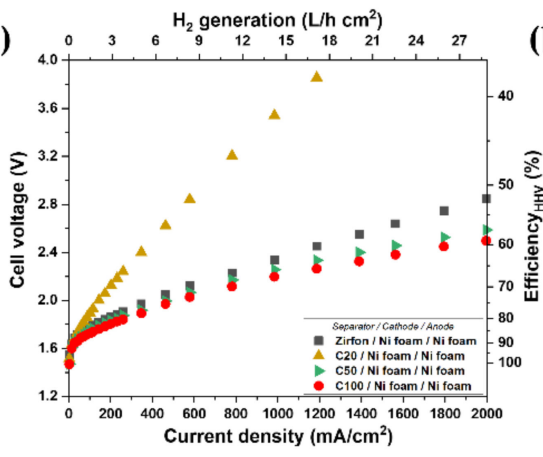

(c)

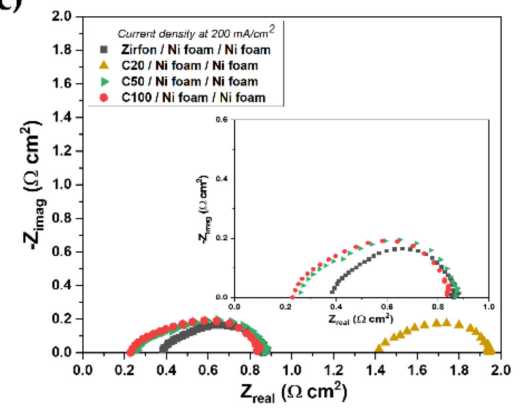

(b)

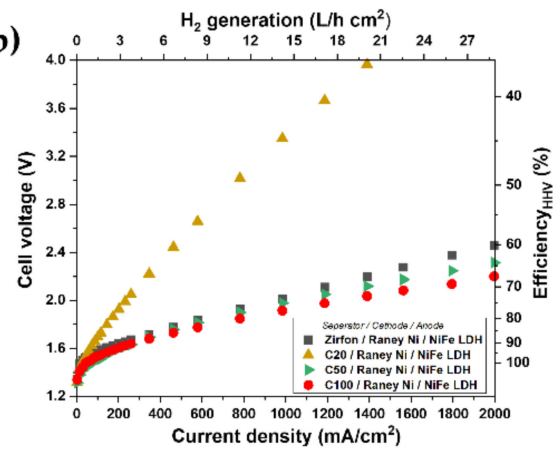

(d)

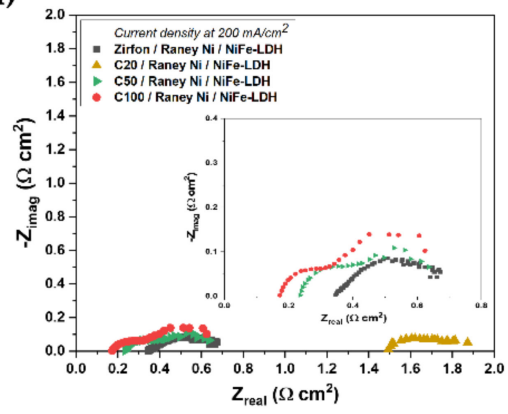

Figure 5. In-situ polarization curve and impedance spectra of a single cell with $(\mathbf{a}, \mathbf{c}) \mathrm{Ni}$ foam/ cathode - Ni foam/anode and (b,d) Raney Ni/cathode-NiFe Layard double hydroxide (LDH)/anode in $30 \mathrm{wt} \%$ potassium hydroxide $(\mathrm{KOH})$ solution at $80{ }^{\circ} \mathrm{C}$ (the inset showed the closed-up at low impedance range). 
The structural stability of the spent Zirfon and $\mathrm{CeO}_{2}$-based separators after the in-situ cell test was further studied by XRD and cross-sectional SEM analysis as given in Figure 6. The XRD pattern of the Zirfon separator shows no peak shift compared with the standard card of monoclinic $\mathrm{ZrO}_{2}$ (Figure 6a) and the $\mathrm{CeO}_{2}$-based separators exhibit good agreement with standard JCPDS Cubic $\mathrm{CeO}_{2}$ phase without any other impure peaks (Figure 6b). Their cross-sectional SEM images are shown from Figure $6 \mathrm{c}-\mathrm{f}$. The morphology of spent Zirfon and $\mathrm{CeO}_{2}$-based separators show the negligible difference as compared to pristine separators (Figure $1 \mathrm{e}-\mathrm{h}$ ). These results suggest that the $\mathrm{CeO}_{2} / \mathrm{PSU}$ composites exhibit their chemical and physical stability under harsh operating conditions, such as high current density $\left(\sim 2000 \mathrm{~mA} \mathrm{~cm}^{-2}\right)$, temperature of $80{ }^{\circ} \mathrm{C}$, and $30 \mathrm{wt} \% \mathrm{KOH}$ electrolyte.
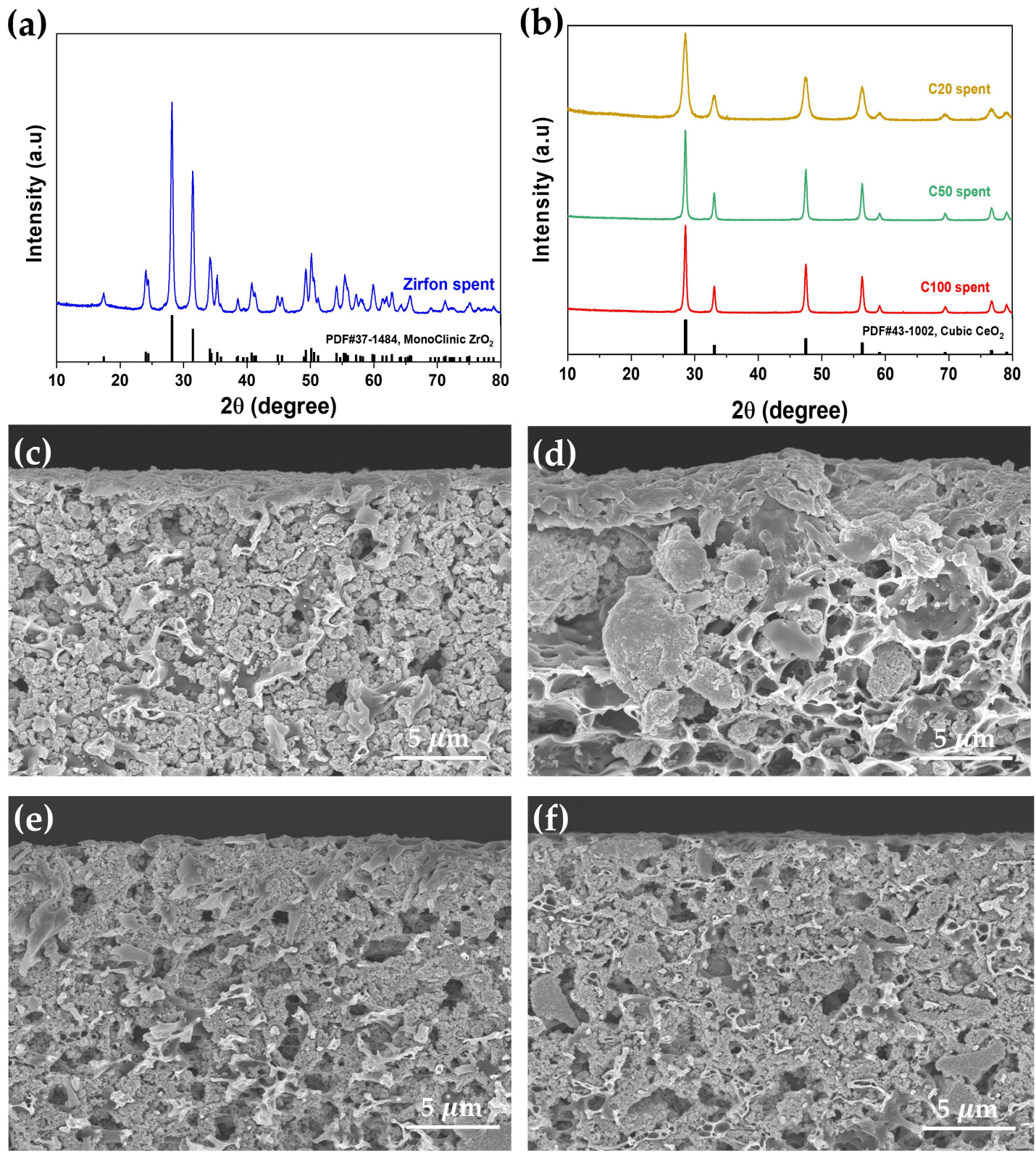

Figure 6. XRD patterns of spent (a) Zirfon separator, (b) $\mathrm{CeO}_{2}$-based separators, including C20, C50 and C100, and cross-section SEM images of spent (c) Zirfon separator, (d) C20 separator, (e) C50 separator and (f) C100 separator. The "spent" represent the separator after electrochemical test up to $2000 \mathrm{~mA} \mathrm{~cm}^{-2}$ at $30 \mathrm{wt} \% \mathrm{KOH}$ and $80^{\circ} \mathrm{C}$. 


\section{Conclusions}

In this paper, we presented a $\mathrm{CeO}_{2}$-based porous separator that outperforms the commercial Zirfon separator in terms of ohmic resistance and $\mathrm{H}_{2}$ permeability. The $\mathrm{CeO}_{2}$-based porous separator was synthesized by varying the $\mathrm{CeO}_{2}$ nanoparticle size. The porous separator with the addition of $100 \mathrm{~nm} \mathrm{CeO} 2$ nanoparticles reduced the average pore size while enhancing the wettability. The $\mathrm{C} 100$ separator-equipped alkaline cell achieved $800 \mathrm{~mA} \mathrm{~cm}^{-2}$ at $1.84 \mathrm{~V}$ for the Raney-Ni-catalyzed HER and NiFe LDH-catalyzed in $30 \mathrm{wt} \% \mathrm{KOH}$ electrolytes and it exhibited much low $\mathrm{H}_{2}$ permeability. The results demonstrated in this study show that $\mathrm{CeO}_{2}$ nanoparticles can be used as organic materials for highly ionic conductive and low gas permeable porous separators.

Author Contributions: Conceptualization, W.C.C.; Validation, M.K., S.-K.K.; Methodology, M.K., H.-S.C.; Data Curation, S.-K.K., H.-S.C.; Resources, J.H.L.; Formal Analysis, J.H.L., C.L., J.H.J., C.-H.K.; Investigation, C.L., J.W.L.; Writing-Original Draft Preparation, J.W.L., W.C.C.; Writing-Review \& Editing, W.C.C., J.H.J., C.-H.K.; Visualization, J.W.L.; Supervision, W.C.C., J.H.J. All authors discussed the results and co-wrote the paper. All authors have read and agreed to the published version of the manuscript.

Funding: This study was supported by the Korea Institute of Energy Technology Evaluation and Planning (KETEP) and the Ministry of Trade, Industry \& Energy (MOTIE) of the Republic of Korea (2019281010007A and 20203030040030). This research was also supported by the Hydrogen Energy Innovation Technology Development Program of the National Research Foundation of Korea (NRF) funded by the Korean government (Ministry of Science and ICT (MSIT)) (NRF- 2015M1A2A2074657 and NRF-2019M3E6A1064020).

Conflicts of Interest: The authors declare no conflict of interest.

\section{References}

1. Götz, M.; Lefebvre, J.; Mörs, F.; Koch, A.M.D.; Graf, F.; Bajohr, S.; Reimert, R.; Kolb, T. Renewable Power-to-Gas: A technological and economic review. Renew. Energy 2016, 85, 1371-1390. [CrossRef]

2. Tjarks, G.; Mergel, J.; Stolten, D. Dynamic operation of electrolyzers-systems design and operating strategies. Hydrog. Sci. Eng. Mater. Process. Syst. Technol. 2016, 309-330. [CrossRef]

3. Santos, D.M.F.; Sequeira, C.A.C.; Figueiredo, J.L. Hydrogen production by alkaline water electrolysis. Quim. Nova 2013, 36, 1176-1193. [CrossRef]

4. Pushkareva, I.V.; Pushkarev, A.S.; Grigoriev, S.A.; Modisha, P.; Bessarabov, D.G. Comparative study of anion exchange membranes for low-cost water electrolysis. Int. J. Hydrogen Energy 2020, 45, 26070-26079. [CrossRef]

5. Park, J.E.; Kang, S.Y.; Oh, S.H.; Kim, J.K.; Lim, M.S.; Ahn, C.Y.; Cho, Y.H.; Sung, Y.E. High-performance anion-exchange membrane water electrolysis. Electrochim. Acta 2019, 295, 99-106. [CrossRef]

6. Schmidt, O.; Gambhir, A.; Staffell, I.; Hawkes, A.; Nelson, J.; Few, S. Few Future cost and performance of water electrolysis: An expert elicitation study. Int. J. Hydrogen Energy 2017, 42, 30470-30492. [CrossRef]

7. Estermann, T.; Newborough, M.; Sterner, M. Power-to-gas systems for absorbing excess solar power in electricity distribution networks. Int. J. Hydrogen Energy 2016, 41, 13950-13959. [CrossRef]

8. Olivier, P.; Bourasseau, C.; Bouamama, P.B. Low-temperature electrolysis system modelling: A review. Renew. Sustain. Energy Rev. 2017, 78, 280-300. [CrossRef]

9. Qadrdan, M.; Abeysekera, M.; Chaudry, M.; Wu, J.; Jenkins, N. Role of power-to-gas in an integrated gas and electricity system in Great Britain. Int. J. Hydrogen Energy 2016, 40, 5763-5775. [CrossRef]

10. Tham, D.D.; Kim, D. C2 and N3 substituted imidazolium functionalized poly(arylene ether ketone) anion exchange membrane for water electrolysis with improved chemical stability. J. Membr. Sci. 2019, 581, 139-149. [CrossRef]

11. Fortin, P.; Khoza, T.; Cao, X.; Martinsen, S.Y.; Barnett, A.O.; Holdcroft, S. High-performance alkaline water electrolysis using Aemion ${ }^{\mathrm{TM}}$ anion exchange membranes. J. Power Sources 2020, 451, 227814. [CrossRef]

12. Li, D.; Park, E.J.; Zhu, W.; Shi, Q.; Zhou, Y.; Tian, H.; Lin, Y.; Serov, A.; Zulevi, B.; Baca, E.D.; et al. Highly quaternized polystyrene ionomers for high performance anion exchange membrane water electrolysers. Nat. Energy 2020, 5, 1-8. [CrossRef]

13. Suermann, M.; Kiupel, T.; Schmidt, T.J.; Buchi, F.N. Electrochemical hydrogen compression: Efficient pressurization concept drived from an energetic evalution. J. Electrochem. Soc. 2017, 164, F1187-F1195. [CrossRef] 
14. Corgnale, C.; Greenway, S.; Motyka, T.; Sulic, M.; Hardy, B.; Molten, T.; Ludlow, D. Technical performance of a hybrid thermo-electrochemical system for high pressure hydrogen compression. ECS Trans. 2017, 80, 41. [CrossRef]

15. Marino, M.G.; Melchior, J.P.; Wohlfarth, A.; Kreuer, K.D. Hydroxide, halide and water transport in a model anion exchange membrane. J. Membr. Sci. 2014, 464, 61-71. [CrossRef]

16. Parrondo, J.; Arges, C.G.; Niedzwiecki, M.; Anderson, E.B.; Ayers, K.E.; Ramani, V. Degradation of anion exchange membranes used for hydrogen production by ultrapure water electrolysis. RSC Adv. 2014, 4, 9875-9879. [CrossRef]

17. Suzuki, S.; Muroyama, H.; Matsui, T.; Eguchi, K. Influence of $\mathrm{CO}_{2}$ dissolution into anion exchange membrane on fuel cell performance. Electrochim. Acta 2013, 88, 552-558. [CrossRef]

18. Haug, P.; Koj, M.; Turek, T. Influence of process conditions on gas purity in alkaline water electrolysis. Int. J. Hydrogen Energy 2017, 42, 9406-9418. [CrossRef]

19. Baetsle, L.H.; Huys, D. Structure and ion-exchange characteristics of polyantimonic acid. J. Inorg. Nucl. Chem. 1968, 30, 639-649. [CrossRef]

20. Vogt, J.W. Materials for Electrochemical Cell Separators, Report NAS CR72493; NASA Lewis Research Center: Cleveland, OH, USA, 1968.

21. Rakousky, C.; Reimer, U.; Wippermann, K.; Kuhri, S.; Carmo, M.; Lueke, W.; Stolten, D. Polymer electrolyte membrane water electrolysis: Restraining degradation in the presence of fluctuating power. J. Power Sources 2017, 342, 38-47. [CrossRef]

22. Divisek, J.; Mergel, J.; Schmitz, H. Improvement of water electrolysis in alkaline media at intermediate temperatures. Int. J. Hydrogen Energy 1982, 7, 695-701. [CrossRef]

23. Vemiren, P.H.; Leysen, R.; Beckers, H.; Moreels, J.P.; Claes, A. The influence of manufacturing parameters on the properties of macroporous Zirfon@separators. J. Porous Mater. 2008, 15, 259-264. [CrossRef]

24. Schalenbach, M.; Lueke, W.; Stolten, D. Hydrogen diffusivity and electrolyte permeability of the zirfon perl separator for alkaline water electrolysis. J. Electrochem. Soc. 2016, 163, 1480. [CrossRef]

25. Lee, H.I.; Dung, D.T.; Kim, J.; Pak, J.H.; Kim, S.K.; Cho, H.S.; Cho, W.C.; Kim, C.H. The synthesis of a Zirfon-type porous separator with reduced gas crossover for alkaline electrolyzer. Int. J. Energy Res. 2020, 44, 1875-1885. [CrossRef]

26. Charalampides, G.; Vatalis, K.I.; Apostoplos, B.; Ploutarch-Nikolas, B. Rare earth elements: Industrial applications and economic dependency of Europe. Procedia Econ. Financ. 2015, 24, 126-135. [CrossRef]

27. Bambagioni, V.; Bianchini, C.; Chen, Y.; Filippi, J.; Fornasiero, P.; Innocenti, M.; Lavacchi, A.; Marchionni, A.; Oberhauser, W.; Vizza, F. Energy efficiency enhancement of ethanol electrooxidation on $\mathrm{PdCeO}_{2} / \mathrm{C}$ in passive and active polymer electrolyte-membrane fuel cells. ChemSusChem 2012, 5, 1266-1273. [CrossRef]

28. Vermeire, P.H.; Moreels, J.P.; Leysen, R. Porosity in composite Zirfon ${ }^{\circledR}$ membranes. J. Porous Mater. 1996, 3 , 33-40. [CrossRef]

29. Aili, D.; Hansen, M.K.; Andreasen, J.W.; Zhang, J.; Jensen, J.O.; Bjerrum, N.J.; Li, Q. Porous poly (perfluorosulfonic acid) separators for alkaline water electrolysis. J. Membr. Sci. 2015, 493, 589-598. [CrossRef]

30. Xu, L.; Yu, Y.; Li, W.; You, Y.; Xu, W.; Zhang, S. The influence of manufacturing parameters and adding support layer on the properties of Zirfonßseparators. Front. Chem. Sci. Eng. 2014, 8, 295-305. [CrossRef]

31. Li, J.F.; Xu, Z.L.; Yang, H.L.; Yu, Y.; Liu, M. Effect of $\mathrm{TiO}_{2}$ nanoparticles on the surface morphology and performance of microporous PES membrane. Appl. Surf. Sci. 2009, 259, 4725-4732. [CrossRef]

32. Alghunaim, A.; Kirdponpattara, S.; Newby, B.M.Z. Techniques for determining contact angle and wettability of powders. Powder Technol. 2016, 287, 201-215. [CrossRef]

33. Mustain, W.E.; Kohl, P.A. Improving alkaline ionomers. Nat. Energy 2020, 5, 359-360. [CrossRef]

Publisher's Note: MDPI stays neutral with regard to jurisdictional claims in published maps and institutional affiliations. 